$1-1-1954$

\title{
The effect of certain pesticides on nitrification in the soil
}

\author{
H. A. Wilson
}

Follow this and additional works at: https://researchrepository.wvu.edu/ wv_agricultural_and_forestry_experiment_station_bulletins

\section{Digital Commons Citation}

Wilson, H. A., "The effect of certain pesticides on nitrification in the soil" (1954). West Virginia Agricultural and Forestry Experiment Station Bulletins. 366T.

https://researchrepository.wvu.edu/wv_agricultural_and_forestry_experiment_station_bulletins/631 @ WVU. It has been accepted for inclusion in West Virginia Agricultural and Forestry Experiment Station Bulletins by an authorized administrator of The Research Repository @ WVU. For more information, please contact ian.harmon@mail.wvu.edu. 


The Effect of Certain Pesticides On Nitrification in the Soil 


\section{AUTHOR}

H. A. WILSON, author of The Effect of Certain Pesticides on Nitrification in the Soil, is Associate Bacteriologist of the West Virginia University Agricultural Experiment Station and Associate Professor of Bacteriology in the College of Agriculture, Forestry, and Home Economics.

\section{ACKNOWLEDGEMENT}

The author wishes to thank Dr. W. D. Foster, Associate Agricultural Statistician, for assistance with the analysis of variance.

WEST VIRGINIA UNIVERSITY Agricultural EXPEriment Station

College of Agriculture, forestry, and Home Economics

H. R. VARNeY, DiRECTOR

MORGANTOWN 


\section{The Effect of Certain Pesticides On Nitrification in the Soil}

H. A. WILSON

COME of the newer pesticides developed for insect, fungus, and weed $S$ control are detrimental to certain soil organisms or biological soil processes. Unless such pesticides are inactivated in the soil, their value in pest control may be offset by their detrimental effect on the soils.

As a part of a more extensive study of the effect of certain pesticides on the growth of fruit trees when applied to the soil in various amounts, a study was made of the effect of certain fungicides, insecticides, and related chemicals on nitrification in the soil.

Lewis and Hamner (6) found that under normal rates of application for killing weeds, 2,4-D (2,4-dichlorophenoxyacetic acid) had no important effect upon the soil microorganisms or upon plant pathogens in the soil. Azotobacter, according to Verona (12), was not inhibited by 2,4-D and the dinitrocresol types of herbicides when used at the usual rates. Colmer (1) reported that commonly used field application rates of 2,4-D to control weeds in sugar cane fields had no effect upon the Azotobacter population. Increasing the amounts to a level harmful to Azotobacter would be prohibitive for use.

The total number of soil microorganisms was found by Nilsson (7) not to be influenced by a comparatively high concentration of chlorate $\left(\mathrm{NaClO}_{3}\right)$ as long as the chlorate remains in the soil. The soil apparently exhibits a "protective influence" since the organisms are inhibited by a low chlorate content in artificial nutritive solutions. The nitrifying capacity of the soil, however, is strongly inhibited by a chlorate concentration considerably lower than that required for efficient weed control.

Studies on the compatibility of rhizobia with Arasan, Arasan SF, Phygon, Spergon and Spergon-DDT-SL, by Ruhloff and Burton (8), suggested that when chemically-coated seed are inoculated and planted in moist soil, sufficient rhizobia may survive to bring about effective nodulation, but under unfavorable planting conditions, this may not be true.

Smith, Dawson, and Wenzel (10) reported that 2,4-D had no significant effect upon total plate counts of bacteria, actinomyces, and fungi, even at $100 \mathrm{ppm}$ concentration, but the number of nitrite- and nitrateformers were decreased, although recovery took place in ten to forty days. 
Smith and Wenzel (11) found chlordane to be less toxic to the nitrifiers than BHC. Jones (5) reported that both chlordane and BHC had some inhibitory effect upon the nitrifiers when the concentrations of the toxicants were above 1,000 ppm. Saldarraga (9) found BHC, chlordane and toxaphene added to the soil in amounts ranging from $4 \mathrm{~kg}$. to $20 \mathrm{~kg}$. per hectare (approximately 3.5 to 17.5 pounds per acre) had little or no effect upon the total number of bacteria and fungi.

Gamble, Mayhew, and Chappell (3) reported that the herbicides dinitro-o-secondary butyl phenol (3 pounds per acre) and ortho-chlorophenol-sulfonyl fluoride (20 pounds per acre) reduced the respiration rate and plate counts of the saprophytic microflora for three months after treatment. 3 (para-chlorophenyl) 1,1-dimethyl urea (2 pounds per acre) showed a similar reduction for one month.

DDT, under normal usage, was found by Wilson and Choudhri (13) to have no effect upon ammonification and the accumulation of nitrates.

The investigations reported in this bulletin cover the influence of certain fungicides and insecticides upon the nitrification process in the soil, and a comparison of the effect that various salts of dimethyldithiocarbamic acid and zinc ethylene bisdithiocarbamate have upon the nitrification process. The experiments were all made in the laboratory, under controlled conditions. The concentrations of the toxicants in the soil were calculated on the basis of an acre of soil six inches deep with the toxicant equally distributed.

\section{Materials and Methods}

The soil used was a Hagerstown cultivated silt loam obtained from the Experimental Farm at Kearneysville, West Virginia. Soil from the surface four to six inches was collected, air-dried, passed through a 2-mm sieve and thoroughly mixed. The soil had a $\mathrm{pH}$ value of 6.20 .

To $100 \mathrm{gm}$. portions of soil (oven-dried basis) was added $42 \mathrm{mg}$. of nitrogen as ammonium sulfate, and after thorough mixing, the portions were placed in straight-sided water tumblers.

All of the dry toxicants were weighed, added, and thoroughly mixed with the soil. Systox, a liquid, was first diluted with distilled water and added by means of a pipette. After mixing the toxicants and soil, distilled water was added to bring the soil to 45 per cent of its waterholding capacity. The tumblers were covered with heavy kraft paper to reduce evaporation. Incubation was in a constant temperature room at 25 plus or minus $1^{\circ} \mathrm{C}$. The desired moisture level was maintained by adding distilled water semi-weekly.

In one experiment, two concentration levels of the pesticides were used. One concentration was five times the recommended annual 
application of a pesticide for orchard use (4), and the other was twentyfive times the annual application. These concentration levels were designated $5 \mathrm{X}$ and $25 \mathrm{X}$. The pesticides and concentration in parts per million of soil used are given in Table 1. Four replicates were used for each pesticide and each concentration level. Incubation was for thirty days. The data obtained were analyzed statistically according to the analysis of variance method.

Table 1. Pesticides and Concentrations Used (in Parts Per Million of SoIL)

\begin{tabular}{l|r|r}
\hline \hline ToxiCANT & $5 \mathrm{X}$ & $25 \mathrm{X}$ \\
\hline Insecticides & & \\
BHC (10-12 per cent gamma isomer) & 200.0 & 1000.0 \\
Parathion & 13.0 & 250.0 \\
Systox & 250.0 & 65.0 \\
Chlordane & & 1250.0 \\
Fungicides & 187.5 & 937.5 \\
Ferbam & 19.0 & 95.0 \\
Phygon & 75.0 & 375.0 \\
Fixed Copper & \\
\hline
\end{tabular}

The concentrations of toxicants used in the second experiment were not based upon any recommended application. They were applied at the arbitrary rates of $1,50,500,1,000$, and $1,500 \mathrm{ppm}$ of soil. The toxicants used were the dimethyldithiocarbamic acid salts: ferric, zinc, hemi calcium $^{1}$, hemi cadmium and hemi cobalt and zinc ethylene bisdithiocarbamate. The ferric salt will be designated by its common name, ferbam, the zinc salt by ziram, and the zinc ethylene bisdithiocarbamate by zineb. The other three salts are not commercial materials, and will be designated as the hemi calcium salt, the hemi cobalt salt and the hemi cadmium salt. Incubation was at 25 plus or minus $1^{\circ} \mathrm{C}$. for periods ranging from 0 to 180 days.

Following incubation, the samples were placed in quart milk bottles and $2 \mathrm{~N} \mathrm{KCl}$, adjusted to $\mathrm{pH} \mathrm{1.5,} \mathrm{was} \mathrm{used} \mathrm{as} \mathrm{an} \mathrm{extracting} \mathrm{fluid.} \mathrm{The}$ samples in the extracting fluid were shaken for 30 minutes on an equipoise shaker and filtered through two E \& M No. 613 filter papers. Where $\mathrm{pH}$ determinations were made, $10 \mathrm{gm}$. samples (oven dry basis) were removed before the addition of the extracting fluid. These $\mathrm{pH}$ determinations were made with a glass electrode on a soil:water ratio of 1:1.5 after standing, with frequent shakings, for one hour.

Ammonia nitrogen was determined in an aliquot of each extract by the well-known magnesium oxide method. Nitrate nitrogen was determined by the DeVarda's alloy method following the addition of

1The hemi calcium, hemi cadmium and hemi cobalt compounds were kindly furnished sy Dr. H. F. Dletz and Mr. W. N. Longenecker of E. I. du Pont de Nemours and Company, Wilmington, Delaware. 
water to the residue remaining after the ammonia nitrogen had been distilled.

The amount of ammonia nitrogen and nitrate nitrogen in the original soil was less than $1 \mathrm{mg}$. per $100 \mathrm{gm}$. of soil. This was so small that no corrections were made for it.

\section{Results}

The results of the first experiment are shown in Table 2.

In the $5 \mathrm{X}$ series, $20.1 \mathrm{mg}$. of nitrogen in the form of ammonia was recovered from the control which had received $42 \mathrm{mg}$. of nitrogen a ammonia. This would indicate that under the conditions of this ex periment, approximately 50 per cent of the ammonia could be expected to disappear within the incubation period. This agreed with the results obtained from the control for the $25 \mathrm{X}$ series.

Table 2. The Effects of Some Pesticides upon the Nitrification or Ammonium Sulfate when Added to Soll and Incubated for 30 day: AT $25^{\circ} \mathrm{C}$.

\begin{tabular}{|c|c|c|c|c|c|c|c|c|c|}
\hline \multirow{2}{*}{$\begin{array}{c}\text { LEVELS OF } \\
\text { CONCEN- } \\
\text { TRATION }\end{array}$} & \multirow{2}{*}{$\begin{array}{l}\text { FORM OF } \\
\text { NITROGEN }\end{array}$} & \multicolumn{8}{|c|}{ PESTICIDES } \\
\hline & & $\begin{array}{l}\text { CON- } \\
\text { TROL }\end{array}$ & PHYGON & $\mathrm{BHC}$ & $\begin{array}{l}\text { PARA- } \\
\text { THION }\end{array}$ & FERBAM & Systox & $\begin{array}{c}\text { FIXED } \\
\text { COPPER }\end{array}$ & $\begin{array}{c}\text { CHLOR } \\
\text { DANE }\end{array}$ \\
\hline & & \multicolumn{8}{|c|}{ Nitrogen : Mg. per $100 \mathrm{~g}$. Soil } \\
\hline \multirow[t]{2}{*}{$5 \mathrm{X}$} & \multirow{3}{*}{$\begin{array}{l}\mathrm{NH}_{3} \\
\mathrm{NO}_{3}\end{array}$} & 20.1 & 24.5 & 23.4 & 18.1 & 40.9 & 20.7 & 20.1 & 20.0 \\
\hline & & 16.2 & 17.9 & 20.7 & 25.8 & 2.4 & 20.7 & 20.2 & 14.0 \\
\hline Total & & 36.3 & 42.4 & 44.1 & 43.9 & 43.3 & 41.4 & 40.3 & 34.0 \\
\hline \multirow[t]{2}{*}{$25 \mathrm{x}$} & \multirow{3}{*}{$\begin{array}{l}\mathrm{NH}_{3} \\
\mathrm{NO}_{3}\end{array}$} & 20.6 & 35.2 & 34.2 & 18.6 & 46.0 & 20.7 & 21.6 & 26.4 \\
\hline & & 16.4 & 7.1 & 7.6 & 23.7 & 2.4 & 13.5 & 19.4 & 12.7 \\
\hline Total & & 37.0 & 42.3 & 41.8 & 42.3 & 48.4 & 34.2 & 41.0 & 39.1 \\
\hline
\end{tabular}

LSD .95 for $\mathrm{NH}_{3}=11.9$ ) Between materials at one application or LSD .95 for $\mathrm{NO}_{3}=11.3$ ) between levels for one material.

*oven-dry basis.

The amount of ammonia nitrogen recovered from the soil sample treated with various pesticides ranged from $18.1 \mathrm{mg}$. with parathior to $40.9 \mathrm{mg}$. with ferbam. None of the pesticides at the $5 \mathrm{X}$ concentratior seemed to inhibit the nitrification of ammonia, except ferbam. Thi fungicide almost completely inhibited the nitrification process.

In the control, $16.2 \mathrm{mg}$. nitrogen, as nitrate, was found and fron those samples treated with the various fungicides and insecticides, th amount of nitrate nitrogen present ranged from $2.4 \mathrm{mg}$. with ferbam to $25.8 \mathrm{mg}$. with parathion. This was to be expected, inasmuch as th nitrate content increases at the expense of the ammonia nitrogen content

The amount of ammonia nitrogen and nitrate nitrogen found is the control for the $25 \mathrm{X}$ series was almost identical with that from th 
5X control. Ammonia nitrogen recovery in the treated samples ranged from $18.6 \mathrm{mg}$. with parathion to $46.0 \mathrm{mg}$. with ferbam; the control being $20.6 \mathrm{mg}$. The increase in concentration of phygon and BHC resulted in less ammonia disappearing since $35.2 \mathrm{mg}$. and $34.2 \mathrm{mg}$. of ammonia nitrogen respectively were recovered. In fact, the amounts of nitrogen as ammonia recovered from phygon, BHC, and ferbam treated soil at the $25 \mathrm{X}$ concentration were all significantly greater than the control.

At this concentration, the amount of nitrate nitrogen found followed the trend expected on the basis of ammonia recovery. For example, since the amount of ammonia nitrogen recovered from the phygonBHC- and ferbam-treated samples were all significantly greater than the control, less nitrate nitrogen was expected. The ferbam-treated sample, however, was the only one in which the nitrate nitrogen differed signifcantly from the control. The nitrate nitrogen from the samples treated with phygon and BHC were less than that from the control, but the differences were not significant.

The results of the second experiment are shown in Table 3. Three of the toxicants are commercial pesticides, but the hemi calcium, hemi cadmium and hemi cobalt salts of dimethyldithiocarbamic acid are not.

Ferbam-The oxidation of ammonia to nitrate in the control begins to be apparent after 20 days incubation, and this continues throughout the incubation period of 180 days. The amount of nitrate nitrogen found ranged from $1.6 \mathrm{mg}$. to $37.1 \mathrm{mg}$.

A ferbam concentration of $50 \mathrm{ppm}$ apparently has some detrimental effect upon the nitrification of ammonia, since after 40 days of incubation, $32.8 \mathrm{mg}$. of nitrogen as ammonia was recovered as compared with $15.9 \mathrm{mg}$. from the control. This inhibitory effect, however, had almost disappeared after 180 days incubation. This effect is also indicated by the amounts of nitrate nitrogen found.

Ferbam concentrations of 500, 1,000 and 1,500 ppm definitely inhibited nitrification; even after 180 days incubation.

Ziram-This fungicide, chemically similar to ferbam, showed an almost identical inhibitory influence upon nitrification. At a concentration of $50 \mathrm{ppm}$, the inhibitory effect was evident after 40 days incubation, since $34.8 \mathrm{mg}$. of ammonia nitrogen was recovered, as compared to $15.1 \mathrm{mg}$. recovered from the control. Here also, the amounts of ammonia nitrogen and nitrate nitrogen found after an incubation of 180 days were practically equal to the amounts found in the control, indicating that the soil had recovered its nitrifying powers. At higher concentrations, on the other hand, this power to inhibit nitrification, was still evident after 180 days. 

AND Nitrate Recovery

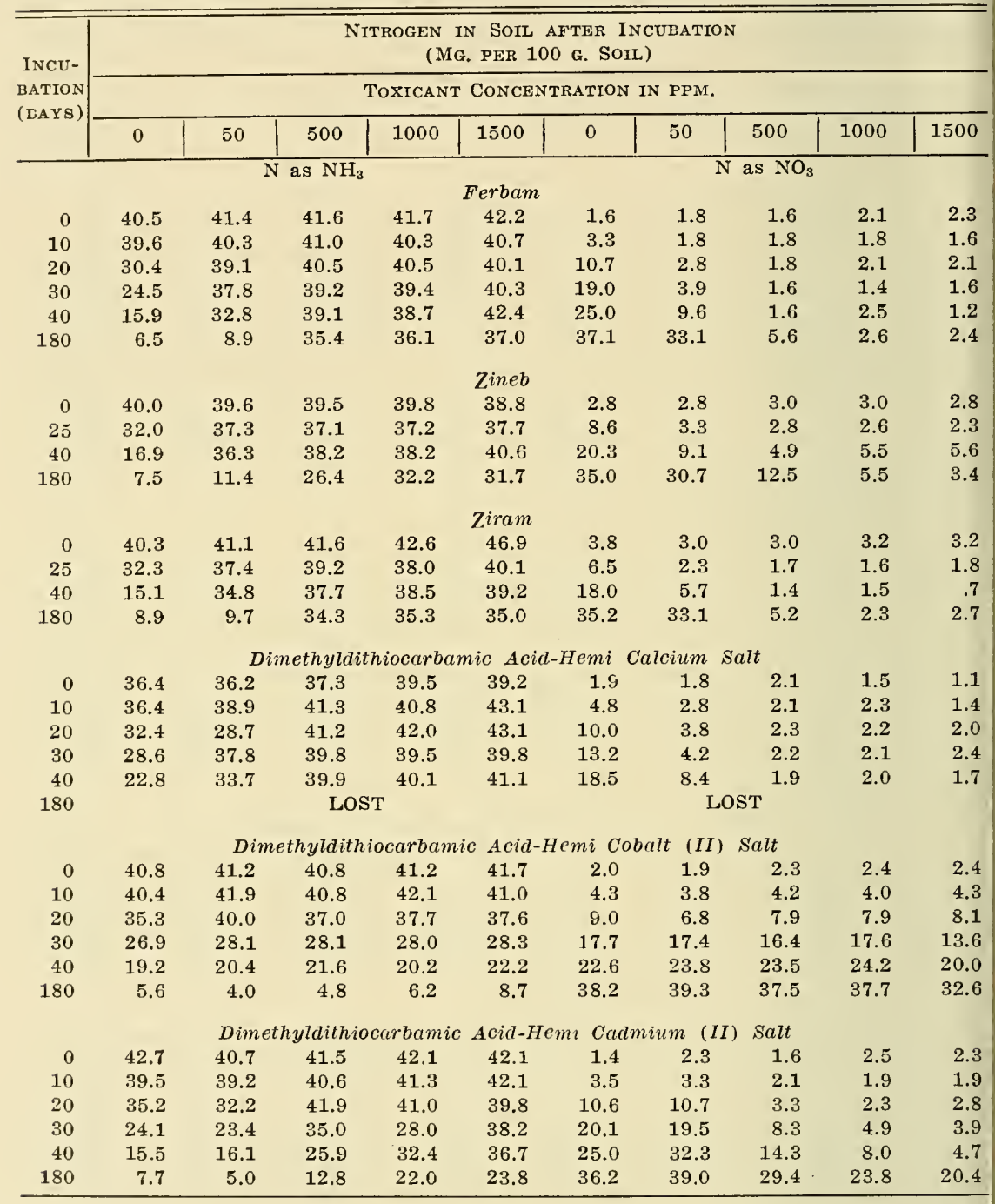

Hemi Calcium Salt-Although the 180-day incubation samples were lost due to a laboratory accident, the data obtained up to 40 days incu bation is, for all practical purposes, similar to those of the ferbam anc ziram treated soil; that is, the nitrifying power appears to be returning where the toxicant concentration was $50 \mathrm{ppm}$, but was still inhibited al the higher concentrations. 
Hemi Cadmium Salt-The recovery of ammonia nitrogen from soil samples receiving this toxicant differs somewhat from the others previously discussed. The amount of ammonia nitrogen recovered from the control after the various periods of incubation corresponds closely to that obtained from the other controls after the same period of incubation. The amount of nitrogen as ammonia recovered from the soil receiving $50 \mathrm{ppm}$ of this salt is practically the same as that recovered from the control at each sampling date.

Ammonia nitrogen recovered at 500, 1,000 and 1,500 ppm is greater than that from the control. However, after 180 days incubation, the amount of ammonia nitrogen recovered from the soil treated with 500 ppm of the hemi cadmium salt is only slightly larger than the amount recovered from the control $(7.7 \mathrm{mg}$.) and from the $50 \mathrm{ppm}$ concentration (5.0 mg.). A greater inhibitory effect was evidenced by the 1,000 ppm and $1,500 \mathrm{ppm}$ concentrations, but this effect was considerably less than that of ferbam and ziram.

Hemi Cobalt Salt-This salt of dimethyldithiocarbamic acid seems to have no influence whatsoever upon nitrification, even at such excessive dosages as $1,500 \mathrm{ppm}$. At every period of incubation, the amounts of both ammonia nitrogen and nitrate nitrogen recovered is practically the same as those recovered from the controls.

Zineb-This compound of the carbamate family seems to be slightly less inhibitory toward nitrification than ferbam, ziram, and the hemi calcium salt, but slightly more so than the hemi cadmium salt. After 40 and 180 days incubation, the amount of ammonia recovered from the soil treated with $50 \mathrm{ppm}$ of this salt is about equal to that recovered after the same incubation interval from ferbam, ziram, and hemi calcium treated soil, but slightly more than that from the soils treated with hemi cadmium and hemi cobalt salts. At the $500 \mathrm{ppm}, 1,000 \mathrm{ppm}$ and 1,500 ppm concentrations, the inhibitory effect is less than that exhibited by ziram, and ferbam, but more than that by the hemi cobalt and hemi cadmium salts.

The original untreated soil had a $\mathrm{pH}$ value of 6.20 . The $\mathrm{pH}$ of the soil in the controls immediately after adding the ammonium sulfate, but before incubation, ranged from 6.03 to 6.23 , the average being 6.15 .

In most cases, the addition of the various toxicants to the soil resulted in a slight increase in the $\mathrm{pH}$ as the concentration of the toxicant increased (Table 4). The highest value found as the result of toxicant addition was $\mathrm{pH} 6.86$ with the hemi calcium salt concentration of 1,500 ppm.

In all the controls, as the ammonia was oxidized to the nitrate, the $\mathrm{pH}$ value decreased. The lowest point reached being $\mathrm{pH} 4.08$ in the 
hemi cobalt series, which corresponded with the lowest amount of ammonia found. The $\mathrm{pH}$ was a good index to the decrease in the amount of ammonia nitrogen. It is quite evident at the $50 \mathrm{ppm}$ concentration that the $\mathrm{pH}$ decreases as the soil regains its nitrifying power. At the higher toxicant concentrations, where little or no nitrification took place, the $\mathrm{pH}$ remained 6.0 or above, even after 180 days incubation.

Table 4. EFfects of Various Toxicants Upon the pH of the Soll

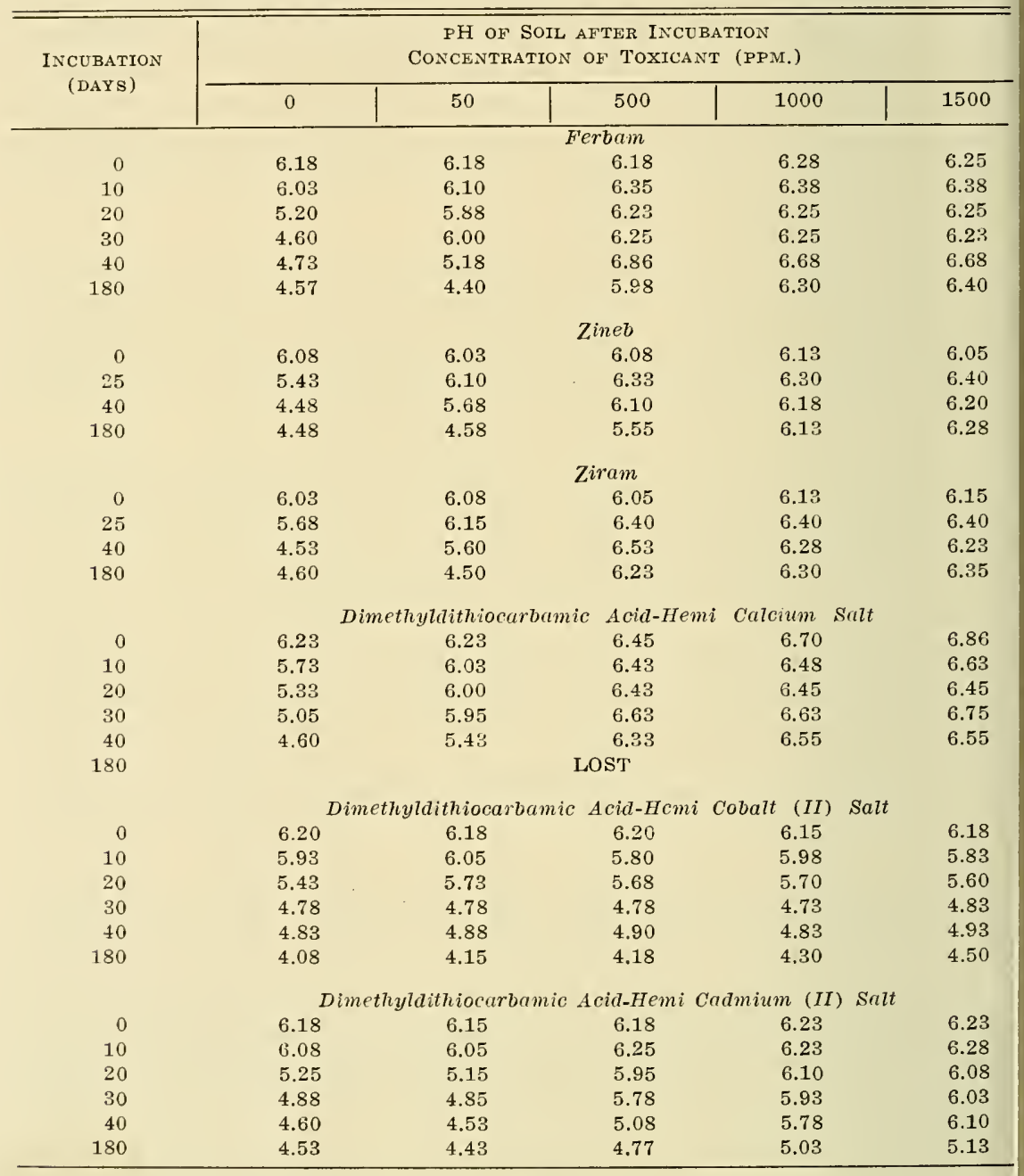




\section{Discussion}

No inhibition of the nitrification process was found in the soil treated with phygon, BHC, systox, fixed copper, parathion, and chlordane at a concentration of five times the recommended annual rate. At this concentration, ferbam, for all practical purposes, completely inhibited the nitrifying capacity of the soil for the duration of the experiment ( 30 days). When the concentration of the different fungicides and insecticides were increased to twenty-five times the recommended annual rate of application, phygon, BHC, as well as ferbam, exhibited an inhibitory effect upon nitrification. The ammonia nitrogen recovered from the soils treated with ferbam at both concentrations, and phygon and $\mathrm{BHC}$ at the $25 \mathrm{X}$ concentration, were all significantly greater than that recovered from the control at the 5 per cent point.

When the amount of nitrate nitrogen found is considered, it is also seen that ferbam at both the $5 \mathrm{X}$ and $25 \mathrm{X}$ concentrations differs significantly from the control, but phygon and BHC, however, were not quite significant at the 5 per cent level. These results are mostly in accord with those of Jones (5). Jones found that chlordane, as well as BHC, has some inhibitory effect upon the nitrifiers when the concentration of the insecticide was above 0.1 per cent $(1,000 \mathrm{ppm})$, but below 0.01 per cent $(100 \mathrm{ppm})$ little danger to the nitrifiers would be expected. Smith and Wenzel (11) also found chlordane and BHC to be toxic to the nitrifiers; chlordane being the less toxic.

It seems safe to assume that phygon will not inhibit soil nitrification as long as no more than 38 pounds per acre per year are used, which is $19 \mathrm{ppm}$ and equivalent to the amount that would be added during a five-year period. BHC apparently would have little or no effect upon the nitrification process up to 400 pounds ( $10-12$ per cent gamma isomer) per acre. This application would be equivalent to $200 \mathrm{ppm}$. Parathion has no inhibitory effect up to 500 pounds per acre or $250 \mathrm{ppm}$, which would be equivalent to the amount that would be applied in twenty-five years at the recommended annual rate. It also seems that systox, fixed copper and chlordane could be used with no danger to the nitrification process in amounts up to 130 pounds, 750 pounds and 2,500 pounds per acre respectively.

Ferbam, on the other hand, is completely inhibitory to the nitrification process at 375 pounds per acre, but this, of course, would be the total of five annual applications. It is also seen in Table 3 that 50 ppm or 100 pounds per acre still shows an inhibitory action after 40 days, but this inhibition had completely disappeared after 180 days. The annual recommended concentration of ferbam, as used in this study, was $37.5 \mathrm{ppm}$ or 75 pounds per acre. Since 100 pounds per acre 
(50 ppm) will inhibit nitrification for at least 40 days, and the recommended annual application is 75 pounds $(37.5 \mathrm{ppm})$, care should be exercised in the use of this fungicide. It also must be borne in mind that these amounts are based on an acre six-inch depth and assuming uniform distribution throughout the depth.

Neither ziram nor zineb should be used much above 100 pounds per acre. The average recommended rates for these materials are in the range of 60 to 100 pounds per acre per year. This is based upon 15-20 pounds of the material per 1 thousand gallons of water and 4 to 5 thousand gallons used per acre.

Since the hemi calcium, hemi cobalt, and hemi cadmium salts of dimethyldithiocarbamic acids are not sold as fungicides or insecticides, interest in their effect upon the nitrification process in the soil is, at least at present, theoretical only. Of these, the hemi calcium salt would seem to be about as inhibitory as ferbam, which would have a critical concentration of about 100 pound per acre or $50 \mathrm{ppm}$. The hemi cadmium salt is somewhat less detrimental to nitrification than the hemi calcium salt, and a soil receiving up to 1,000 pounds per acre would likely recover its nitrifying power almost completely after 180 days. The hemi cobalt salt apparently has no inhibitory effect upon the nitrification process. The reason for this difference in toxicity of the different salts is not known.

It would appear that the dimethyldithiocarbamic acid radical and the ethylene bisdithiocarbamate radical are the inhibitors of the nitrification process, since the ferric, zinc, hemi calcium, and hemi cadmium salts of the former and the zinc salt of the latter all inhibited this process. It has been stated by Frear (2) that the group $>\prod_{S}$ is - is thought to be essential for the insecticidal and fungicidal action of the dialkyl dithiocarbamates. It would be reasonable to assume that this group might also be the inhibitory factor of the nitrification process. However, the hemi cobalt salt is not inhibitory and, if it is found to possess fungcidal properties, should have potential value in controlling fungi under conditions where continued applications result in accumulation of the compound in the soil.

Nitrification takes place in two steps:

$$
\begin{aligned}
& \text { 1. } 2 \mathrm{NH}_{3}+3 \mathrm{O}_{2}=2 \mathrm{HNO}_{2}+2 \mathrm{H}_{2} \mathrm{O} \\
& \text { 2. } 2 \mathrm{HNO}_{2}+\mathrm{O}_{2}=2 \mathrm{HNO}_{3}
\end{aligned}
$$

It is apparent from the data that step 1 is inhibited by the toxic action of all but one of the dithiocarbamates studied. These toxicants have in some manner inhibited the nitrifiers, the bacteria which oxidizes am- 
monia to nitrite. Had step 1 been completed, as was the case with the controls, ammonia nitrogen would have disappeared.

Other workers have pointed out that most of the herbicides, fungicides, and insecticides can be used at their recommended rates with little or no danger to soil organisms or such directly important microbial processes as nitrification. This view is supported by the results of these experiments. It must be remembered, however, that unless such a toxicant becomes inactivated in the soil, it may accumulate to toxic levels. And, it is apparent that even some of the materials used in this study at the higher concentrations still exert their toxicity toward nitrification, even after six months.

This study indicates that all new pesticides should be examined as to their effect upon the soil microorganisms, and also the time required for their inactivation in the soil. If a material disappears slowly or becomes slowly inactivated in the soil, it may accumulate in time to a toxic level.

\section{Summary}

Three fungicides and four insecticides were applied to a soil under laboratory conditions at rates equivalent to five and twenty-five times the recommended annual applications. After 30 days incubation, only the fungicide ferbam inhibited the nitrification process at the lower concentration. At the higher concentration, phygon, BHC, and ferbam were toxic.

The ferric (ferbam), zinc (ziram), hemi calcium, hemi cadmium, and hemi cobalt salts of dimethyldithiocarbamic acid and the zinc ethylene bisdithiocarbamate (zineb) were added to soil under laboratory conditions at $0,50,500,1,000$, and $1,500 \mathrm{ppm}$. Nitrification was inhibited for 40 days at $50 \mathrm{ppm}$ concentration by all the salts, except the hemi cobalt and hemi cadmium salts, but recovery was complete after 180 days.

At 500, 1,000 and 1,500 ppm, the ferric, zinc, and hemi calcium salts of dimethyldithiocarbamic acid and the zinc ethylene bisdithiocarbamate inhibited nitrification almost completely during the 180 days incubation. The hemi cobalt salt showed no inhibitory effect at any concentration used. 


\section{Bibliography}

1. Colmer, Arthur R., "The Action of 2,4-D upon the Azotobacter of Some Sugar Cane Soils." Applied Microbiology, Vol. l (1953), pp. 184-87.

2. Frear, D. E. H., Chemistry of Insecticides, Fungicides and Herbicides. D. Van Nostrand Co., Inc., 1948. (2nd Edition).

3. Gamble, S. J. R., Mayhew, C. J. and Chappell, W. E., "Respiration Rates and Plate Counts for Deternining Effect of Herbicides on Heterotrophic Soil Microorganisms." Soil Sci., Vol. 74 (1952), pp. 347-50.

4. Gould, Edwin and Hamstead, Elwood O., "The Toxicity of Cumulative Spray Residues in Soil." Journ. Econ. Entomol., Vol. 44 (1951), pp. 713-17.

5. Jones, L. W., "Are Insecticides Toxic to Soil Microorganisms?" Farm and Home Sci., II (3) (1950), pp. 58-9.

6. Lewis, Ralph W. and Hamner, Charles L., "The Effect of 2,4-D on Some Microorganisms." Quar. Bul., Mich. State Coll. Agr. Exp. Sta. 29 (1946), pp. 112-14.

7. Nilsson, Eric, "The action of Chlorate on Some Microbial Phenomena in the Soil." Ann, Roy. Agr. Coll. Sweden, Vol. 18 (1951), pp. 60-73.

8. Ruhloff, Marcia and Burton, Joe C., "Compatibility of Rhizobia with Seed Protectants." Soil Sci. Vol. 72 (1951), pp. 283-90.

9. Saldarriga Velez, Alfredo, "Influencia de tres insectiadas sobre la poblacion de microorganismos del suelo." Acta Agronomica (Nat. Uni. Colombia) Vol. 4 (1954), pp. 45-67.

10. Smith, N. R., Dawson, V. T., and Wenzel, M. E., "Effect of Certain Herbicides on Soil Microorganisms." Soil Sci. Soc. Amer. Proc., Vol. 10 (1946), pp. 197-201.

11. Smith, Nathan R. and Wenzel, Marie E., Soil Sci. Soc. Amer. Proc., Vol. 12 (1947), pp. 227-33.

12. Verona, O., "Effetti di alcuni exbicidi selettivi sulla microflora, in particolare, del terreno." Ann. Fac. Agrar. Uni. Pisa., Vol. 9 (1948), pp. 189-199. (Soils \& Fertilizers-Abst., Vol. 13 (1950), p. 53

13. Wilson, J. K. and Choudhri, R. S., "Effects of DDT on Certain Microbiological Processes in the Soil." Jour. Econ. Entomol., Vol. 39 (1946), pp. 537-38. 



\section{tols}

